\title{
Using the Facebook Iframe as an Effective Tool for Collaborative Learning in Higher Education
}

\author{
Mohamed A. Amasha \\ Department of Computer Teacher Preparation, \\ Damietta University. \\ Damietta , Egypt
}

\author{
Salem Alkhalaf \\ College of Science and Arts, Computer Science Department, \\ Qassim University \\ Alrass City, Saudi Arabia
}

\begin{abstract}
Facebook is increasingly becoming a popular senvironment for online learning. Despite the popularity of using Facebook as an e-learning tool, there is a limitation when it comes to presenting content: another platform is required to run the files. Presented in this paper is a case study of how the Facebook iframe code can be used as a hosting environment tool to support collaborative activities in higher education at Qassim University. The study was conducted on a sample of $(N=45)$ university students who were enrolled in Selected Topics in Information Systems (INFO491) at the Faculty of Art \& Science at Qassim University. We used Facebook markup language (FBML) to design and implement the course. An online questionnaire was used to investigate the students' perceptions about using Facebook iframe for the course. Descriptive statistical analysis and chi-square test were used to analyze the data. According to our results, the participants reported that using the Facebook iframe page increased their understanding and improved their learning performance. In addition, for the majority of students, it enabled them to learn more quickly. Our findings also revealed that a Facebook iframe page is a distinctive hosting environment for presenting content.
\end{abstract}

Keywords-Facebook iframe; collaborative learning; Facebook markup language (FMBL); hosting environment

\section{INTRODUCTION}

Facebook has become an effective tool for e-learning and the most popular social networking site for college students [2], [18]. It is used as an e-learning tool in enhancing learner course outcomes. In addition, it offers great potential for teaching and learning [21]. It enables teachers to engage in three major types of interaction: learner-to-instructor interaction, learner-to-learner interaction, and learner-tosubject interaction [10], [31]. With Facebook, a structural equation model is constructed which examines the relationships between factors affecting this adoption process in relation to the user's existing purposes [25]. A previous study entailed the use of Facebook for three-way communication and as an interaction tool [16]. As a useful and meaningful learning environment, it can support, enhance, and/or strengthen student learning [14], [23]. As previous studies have shown, there are some constraints of using Facebook as an e-learning tool [1]: 1) Facebook does not support many file formats that need to be uploaded directly; 2) file size is limited for Facebook uploads; and 3) students cannot control the content via navigation buttons. One possible way of using Facebook is to use its iframe to host the course content and share resources, upload files, make announcements, and conduct online discussions between teacher and students. The main purpose of this study was to describe how the Facebook iframe was used as a hosting environment of content and to report students' perceptions about it. We expected that the use of Facebook iframe would be a better way to host the content as well as deliver it to and share it with students. Hosting content in the Facebook canvas enables students to control the content and navigate through it. We hoped to improve each student's ability to use Facebook as a learning tool. The results were expected to provide insights into promoting the use of Facebook iframe in a collaborative learning environment.

\section{LITERATURE REVIEW}

\section{A. Social Network}

The $21^{\text {st }}$ century has witnessed a great revolution, especially in the field of information and communications technology (ICT). This was accompanied by the appearance of some new techniques and applications, which make the user a positive participant in knowledge creation rather than being just a passive recipient. Social media is considered among these innovations of modern technology [17]. Social networks are no longer used only in communication and chatting with friends; they have become transparent and interactive learning atmospheres in which the learner is an active participant in the educational process. Using social media facilitates communication and creates an effective network worldwide [14]. Many teachers use online websites on a daily basis personally without being aware of how to activate those websites in education [13]. Facebook, for example, is one of the most popular social networks. It is ranked as the ninth best learning tool worldwide [2]. Nowadays, social media has become a part of our daily lives and changed the way people communicate. It is now used for communication, collaboration, and learning. It is one of the daily routines for learners, where professors can follow students' learning process as well. Facebook has become a tool for learning used by teachers in schools, and it is also used in universities as a learning management system (LMS) [5]. Facebook is considered the most widely used social network in the educational field; there are various schools and universities and educational institution using it in the learning process. There are many ideas for using Facebook inside the classroom that both teachers and professors can apply easily. In addition, it can be used as a revision tool on which the teacher can post notes or a summary after each lesson [19]. Moreover, it can be 
used as an advertisement board and as a way to share sites, files, and multimedia which support student learning and broaden their understanding [32]. Facebook can also be used as a study group. The teacher can divide the students into groups to discuss the lessons or the projects with each other, and the teacher's role is to follow the discussions and provide encouragement [24]. It is also a tool for communicating with parents to inform them about the level of their children or summer activities through special pages used for this purpose [27], [3].

\section{B. Facebook as Learning Tool}

Facebook is considered a learning platform, which hosts many new strategies for teaching as learning based on projects, solving problems, brainstorming, and teaching strategies. Facebook, with tools and potential, can contribute in raising the level of motivation of learners and improve the environment of the classroom, in addition to improving the relation between the students and teachers. The Facebook environment provides two types for interaction and feedback: syndication through the chat tool on Facebook and no syndication through Facebook pages or groups. Based on this research, Facebook was chosen to be the host site because it has distinguished features that are not available on other social networking sites. Presented in this study is a model of teaching and learning for using the Facebook iframe that is, it helps to host iframe code in a Facebook canvas [16]. Facebook is considered one of the most efficient sources of information for learners. It provides them with productive skills according to their needs, interests, and aspirations. The aim of this research is to make use of the available computer technology in the field of education. Facebook is effectively used as an LMS for e-learning and as a device to improve elearning courses [24]. The most recent adaptation of e-Front is made with an arrangement of social apparatuses that encourage the utilization of Facebook as a LMS for e-learning. It comes with a simple Facebook integration plug-in for easy use. E-Front is an open source of learning management system with an attractive appearance and is SCORM certified. EFront encourages group learning and maintains standards of aggregate information [8]. Utilizing familiar technologies that students are comfortable with, such as Facebook, helps in developing a successful learning environment. It makes good use of the creative, interactive, and collaborative nature of Facebook [4]. The goal of these technologies is to meet learners' needs, and they are useful in helping them accomplish their educational purposes [12].

On Facebook, an instructor can begin a closed group that is inaccessible in Facebook. This group will be effective for publishing information and getting feedback from the students [24]. Additionally, these groups will be useful for posting homework, links for further study, and declarations; sharing ideas; and socializing after school hours [30]. The reasons using Facebook in education was chosen for this study are as follows:

- The large number of network users.

- The availability of e-mail, forums, and chat, which work as a learning environment.
Therefore, the subject of Facebook was chosen to uncover the explanations behind its educational value [14]. The network enables us to socialize, chat, and communicate easily with our relatives and friends at no cost. We can share our opinions and thoughts about what is going on around the world. In addition, at the same time, we get immediate feedback on what we write or share. Thus, Facebook is considered the best means of interaction and communication. It also has strong privacy settings that maintain confidentiality according to the user's preferences [26].

\section{Aim}

The aim of the current study was to examine students' perceptions of using Facebook iframe as a hosting environment of the content of to support learning.

\section{METHODOLOGY}

\section{A. Course Design and Implementation}

\section{1) Context:}

In this study, Facebook markup language was used to design the elective course for undergraduate students at the Faculty of Science \& Art at Qassim University. In this course 31 students were enrolled. Sessions were presented twice a week, and each session lasted for two hours. One session of the course per week was presented face-to-face, and the other session was presented online. The course addressed some topics in relation to the subject of e-learning.

\section{2) Setting up Facebook iframe page and course materials:}

A Facebook page was created, and then an iframe static tab was added to the page (http://statictab.com/v4pa9jw). The content of the course was created using PowerPoint and was converted into a video file using the SnagIt application. A Google drive (https://drive.google.com/drive) was used to upload the content and to obtain iframe tags and HTML (hypertext markup language) code. We developed HTML (hypertext markup language) code to add lectures to the Facebook iframe page. The following tags are a sample of HTML code inside a Facebook iframe page:

$$
\begin{aligned}
& \langle\mathrm{p}\rangle\langle/ \mathrm{p}\rangle \\
& <\text { div align="CENTER" style color }=" \text { ffff00" }>
\end{aligned}
$$

$<$ h1 $>$ E-learning lecture $</$ h $1>$

$</$ div $>$

$\begin{array}{cc}<\text { iframe } & \text { src="https://archive.org/embed/rrrrrrrrrr_453" } \\ \text { height="480" } & \text { frameborder="0" }\end{array}$ webkitallowfullscreen="true" mozallowfullscreen="true" allowfullscreen $\rangle\langle$ iframe $\rangle\langle$ br $\rangle\langle$ br $\rangle$

$<$ center $><\mathrm{a} \quad$ href="http://statictab.com/zgo2sxm" target="_blank" $><$ input type="submit" style="width: 200px;" value $=$ "main page " name $=$ "B1" $/\rangle\langle/ \mathrm{a}\rangle\langle/$ center $\rangle\langle$ br $/\rangle<$

<center ><ahref="http://statictab.com/sfgmg47" target="_blank" $><$ input type="submit" style="width: 200px;" value="lecture1" name="B1" $/\rangle\langle/$ a $\rangle\langle/$ center $\rangle\langle$ br $/\rangle\langle$ br $/\rangle$.

3) Setting up a Facebook group 
A Facebook closed group (INFO490) was created before starting the course. We asked students to set up their own profiles, and then they were invited to join the group. There were 45 students in this group. We provided the students with instructions and urged them to abide by the ethics of the group. After that, the researchers instructed the students to access the Facebook page and to participate in the activities of the page and view lectures on a regular basis.

\section{4) Organizing lectures}

Lectures were organized in the form of educational programs, allowing students to control and navigate to content. Weekly materials were added to the iframe page. Once the lecture material was created and uploaded on Google drive, the iframe code was generated and posted on Facebook iframe. The Facebook iframe page subscribed to the materials on the Facebook page, so Facebook became a hosting environment for the content and students had control of it. The researchers used the discussion board to ask questions, and this board was, for the most part, used on a weekly basis. Fig. 1 shows the educational program icon on the Facebook iframe page. Fig. 2 shows the content of the first lecture.

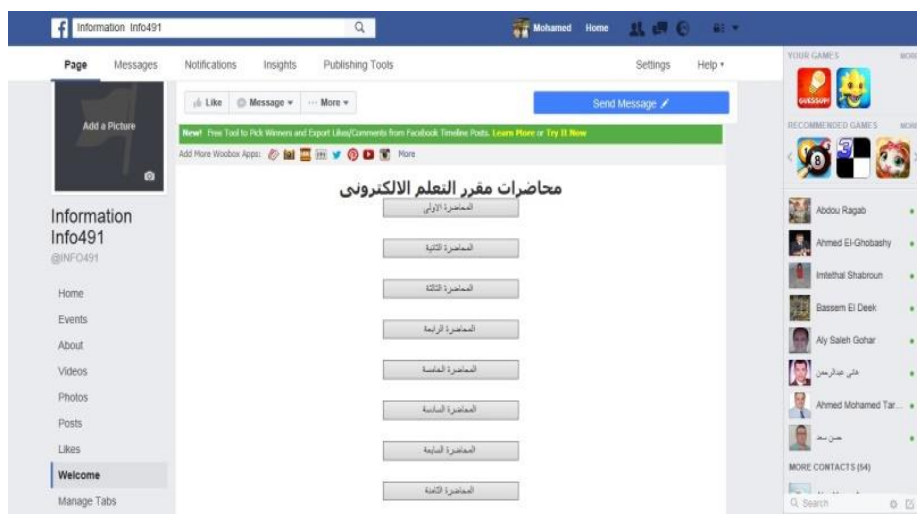

Fig. 1. Educational program icons on the Facebook iframe page.

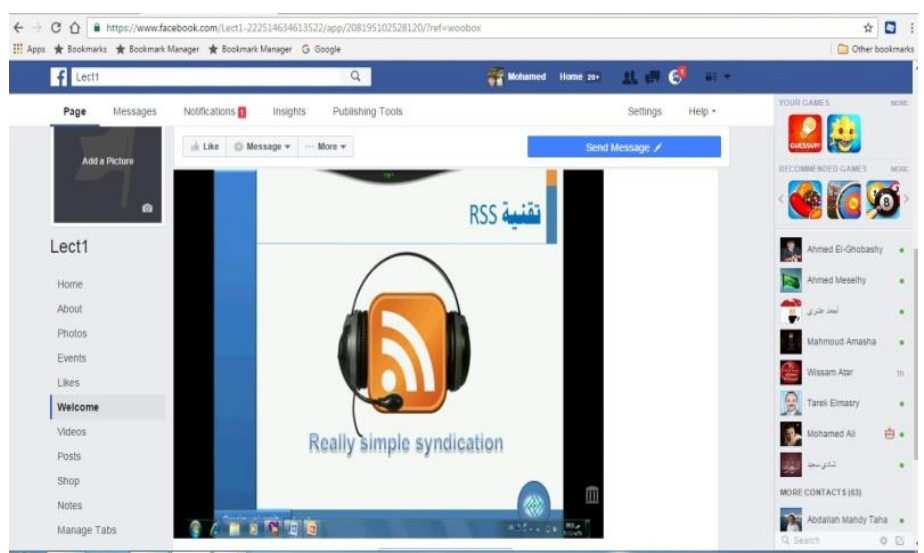

Fig. 2. Shows the content of the first lecture.

\section{B. Participants}

The study was conducted at Qassim University during the first semester of the 2016 academic year. The participants were 45 graduate students who were enrolled in a course entitled Selected Topics in Information Systems (INFO491). All participants were invited to create a Facebook page if they had not already and invited to participate in the Facebook group (INFO 491). As was previously mentioned, the course sessions were held twice a week; one of these was face-toface, and the other was online through the Facebook iframe page. After completing the learning of the course, all participants were asked to respond to an online survey at (https://goo.gl/forms/EEJL2Xv7VZmZUX6I3). In Table 1, the demographic profile is summarized. It includes participants' genders, ages, and opinions about using Facebook for learning. In total, 45 students participated in the study. Twenty-one of them were female $(46.67 \%)$, and twenty-four were male $(53.33 \%)$. The results in Table 1 show that $84.44 \%$ of Facebook users were 20-30 years old. Thirty-three participants $(73.33 \%)$ use Facebook 5-10 times daily. About 42 participants $(93.33 \%)$ do not mind using Facebook in elearning courses, and a majority of them would not mind using Facebook iframe as a hosting environment tool to present content $(93.33 \%)$. They think it would be useful for them, and it would give them the opportunity to exchange experiences and connect daily with their classmates.

\section{Instrument}

In this study, an online questionnaire was developed to investigate students' attitude toward the use of the Facebook iframe page as a learning tool. The questionnaire was designed with a 5-point Likert scale: ( $1=$ strongly disagree, $2=$ disagree, $3=$ slightly agree, $4=$ agree, $5=$ strongly agree). It consisted of 23 closed-ended questions and had five sections: Facebook Self-efficacy (SE); Attitude toward Facebook Iframe (AT); Behavioral Intention (BI); Outcomes and Usefulness (OU); and Ease of Use (EU). Students were invited to follow the Google drive link to respond to the questionnaire, and we mailed the questionnaire to students that enrolled in the course $(\mathrm{N}=45)$. A Google spreadsheet was used to collect data. Ten experts validated the questionnaire, and its internal reliability was found to be good. The Cronbach's $\alpha$ coefficient was 0.745 .

\section{Data analysis}

All analyses were conducted using the SPSS statistical software package version 20.0. Frequency distributions, mean score, and standard deviation were calculated for each item from the online questionnaires in the spreadsheet. Chi-square test was used to compare between actual and prospective students' responses regarding the use of the Facebook iframe page as an effective learning tool for the Selected Topics in Information System (INFO491) course. Statistical significance level was set at $\mathrm{p}<0.05$. 
TABLE I. SAMPLE DEMOGRAPHIC INFORMATION

\begin{tabular}{|l|c|c|}
\hline \multicolumn{1}{|c|}{ Items } & $\begin{array}{c}\text { Frequency } \\
(\mathbf{n = 4 5})\end{array}$ & $(\%)$ \\
\hline Gender & 24 & 53.33 \\
\hline Male & 21 & 46.67 \\
\hline Female & & \\
\hline Age & 3 & 6.67 \\
\hline $20-25$ & 38 & 84.44 \\
\hline $26-30$ & 4 & 8.89 \\
\hline $30+$ & 6 & 13.33 \\
\hline Facebook usage & 33 & 73.33 \\
\hline One a day & 5 & 11.12 \\
\hline 5-10 times a day & 1 & 2.22 \\
\hline $10-15$ times a day & & \\
\hline More than 15 times a day & 42 & 93.33 \\
\hline $\begin{array}{l}\text { Opinion } \text { about Facebook in learning } \\
\text { courses }\end{array}$ & & \\
\hline It isn't suitable as an educational tool. & 1 & 2.22 \\
\hline Communicate to my friends. & 2 & 4.44 \\
\hline I would not mind. & & \\
\hline
\end{tabular}

\section{RESUlTS AND DisCUSSION}

The aim of the current study was to examine students' perceptions of using Facebook iframe as a hosting environment of the content of to support learning. The results suggest that Facebook iframe may be useful in supporting students' learning outcomes. Also, students find the presentation of course content through Facebook iframe page is effective, efficient, and easy to use. Prior studies conducted revealed that, despite their agreement with the importance of Facebook as a learning environment, students had difficulty viewing the course content [33], [29], [14]. In our study, the use of the Facebook iframe page as a hosting learning tool changed students' attitudes toward using Facebook as a learning tool. This change was evident in our results, which show that students are influenced to adopt Facebook because they want display all the content on the Facebook page in the form of an educational program and not have to move to other web pages or obtain additional software. In addition, students want to establish or maintain contact with other people with whom they share interests and values. The results indicate that Facebook Self-efficacy (SE), Attitude toward Facebook Iframe (AT), Behavioral Intention (BI), Outcomes and Usefulness (OU), and Ease of Use (EU) have a significant positive influence on Adoption of Facebook [7]. The responses to the current study's survey items reveal that students prefer the use of the Facebook iframe rather than the Facebook wall as a learning tool. Unlike the findings of previous research, which indicated that "participants felt that a Facebook group's wall cluttered with posts would prevent users from noticing critical information and locating important specific content" (Lin, 2016), the results of this research show that using the Facebook iframe page as a hosting environment is more attractive and effective than the use of Facebook as a content organizer. These results agree with the findings of previous studies that involved using Facebook as learning tool [22], [15], [20] and our study of using Facebook as a hosting environment. In this study, a correlational analysis between the constructs was conducted to explore associations among them. The results in Table 2 indicate that Outcomes and Usefulness is positively and significantly correlated with Attitude toward Facebook Iframe (0.707; p < .01); Behavioral Intention $(0.105 ; \mathrm{p}<.01)$; and Attitude toward Facebook Iframe $(0.700 ; p<.01)$. Facebook Ease of Use is also found to be positively correlated with Facebook Self-efficacy (0.679; $\mathrm{p}<.01)$.

TABLE II. A CORRELATION MATRIX BETWEEN CONSTRUCTS

\begin{tabular}{|c|c|c|c|c|c|}
\hline Constructs & \multicolumn{1}{l|}{ SE } & AT & BI & OU & EU \\
\hline SE & - & & & & \\
\hline AT & 0.598 & - & & & \\
\hline BI & 0.130 & 0.039 & - & & \\
\hline OU & 0.700 & 0.707 & 0.105 & - & \\
\hline EU & 0.685 & 0.662 & 0.130 & 0.679 & - \\
\hline
\end{tabular}

2-tailed $\mathrm{p}$ values; ${ }^{*} \mathrm{p}<0.05,{ }^{* *} \mathrm{p}<0.01$.

Facebook Self-efficacy (SE), Attitude toward Facebook Iframe (AT), Behavioral Intention (BI), Outcomes and Usefulness (OU), Ease of Use (EU)

TABLE III. PERCEPTIVE AND ChI-SQUARE TESTING

\begin{tabular}{|c|c|c|c|}
\hline & Mean(SD) & $\begin{array}{c}\text { Cronbach's } \\
\text { Alpha }\end{array}$ & $\begin{array}{c}\text { Chi-square } \\
\mathrm{x}^{2}\end{array}$ \\
\hline Facebook Self-efficacy: & & & \\
\hline $\begin{array}{l}\text { I have the basic skills for } \\
\text { using Facebook iframe page. }\end{array}$ & $3.51(1.12)$ & \multirow{4}{*}{0.644} & $\begin{array}{l}14.88 \\
(p=0.005)\end{array}$ \\
\hline $\begin{array}{l}\text { I have the skill to deal with } \\
\text { Facebook group and interact } \\
\text { with them. }\end{array}$ & $4.21(.884)$ & & $\begin{array}{l}16.76 \\
(p=0.001)\end{array}$ \\
\hline $\begin{array}{l}\text { Facebook as learning tool is } \\
\text { attractive, motivating. }\end{array}$ & $3.69(1.08)$ & & $\begin{array}{l}16.00 \\
(\mathrm{p}=0.003)\end{array}$ \\
\hline Average & $3.80(1.02)$ & & \\
\hline \multicolumn{4}{|l|}{$\begin{array}{l}\text { Attitude Toward Facebook } \\
\text { iframe: }\end{array}$} \\
\hline $\begin{array}{l}\text { Using Facebook iframe page } \\
\text { makes the learning stay in } \\
\text { long-term memory. }\end{array}$ & $3.76(1.04)$ & \multirow{4}{*}{0.645} & $\begin{array}{l}17.11 \\
(\mathrm{p}=0.002)\end{array}$ \\
\hline $\begin{array}{l}\text { Facebook has to include all } \\
\text { subjects, not just the current } \\
\text { course. }\end{array}$ & $3.20(1.19)$ & & $\begin{array}{l}15.33 \\
(\mathrm{p}=0.004)\end{array}$ \\
\hline $\begin{array}{l}\text { Using Facebook iframe page } \\
\text { as a learning tool is } \\
\text { attractive and amusing. }\end{array}$ & $3.81(1.19)$ & & $\begin{array}{l}20.42 \\
(\mathrm{p}=0.000)\end{array}$ \\
\hline $\begin{array}{l}\text { Using Facebook iframe page } \\
\text { is helpful and more attractive } \\
\text { than traditional learning. }\end{array}$ & $2.82(1.31)$ & & $\begin{array}{l}3.55 \\
(p=0.469)\end{array}$ \\
\hline Average & $3.39(1.18)$ & & \\
\hline \multicolumn{4}{|l|}{ Behavioral Intention: } \\
\hline $\begin{array}{l}\text { I intend to use Facebook } \\
\text { iframe to learn other courses. }\end{array}$ & $3.80(1.14)$ & \multirow[t]{2}{*}{0.840} & $\begin{array}{l}17.77 \\
(\mathrm{p}=.001)\end{array}$ \\
\hline $\begin{array}{l}\text { I feel positive toward using } \\
\text { Facebook iframe as a } \\
\text { learning tool. }\end{array}$ & $3.80(1.19)$ & & $\begin{array}{l}20.44 \\
(\mathrm{p}=.000)\end{array}$ \\
\hline
\end{tabular}




\begin{tabular}{|c|c|c|c|}
\hline & Mean(SD) & $\begin{array}{c}\text { Cronbach's } \\
\text { Alpha }\end{array}$ & $\begin{array}{c}\text { Chi-square } \\
x^{2}\end{array}$ \\
\hline $\begin{array}{l}\text { The Facebook iframe page } \\
\text { was a good learning } \\
\text { environment. }\end{array}$ & $4.04(.92)$ & & $\begin{array}{l}28.66 \\
(p=.000)\end{array}$ \\
\hline $\begin{array}{l}\text { Facebook iframe page was a } \\
\text { good environment to } \\
\text { exchange ideas and share } \\
\text { resources. }\end{array}$ & $3.87(1.08)$ & & $\begin{array}{l}18.11 \\
(\mathrm{p}=.001)\end{array}$ \\
\hline Average & $3.87(1.08)$ & & \\
\hline \multicolumn{4}{|l|}{ Outcomes and Usefulness: } \\
\hline $\begin{array}{l}\text { Using Facebook iframe page } \\
\text { in learning course makes it } \\
\text { easier to learn. }\end{array}$ & $3.89(1.32)$ & \multirow{6}{*}{0.598} & $\begin{array}{l}10.55 \\
(\mathrm{p}=.029)\end{array}$ \\
\hline $\begin{array}{l}\text { Using Facebook iframe page } \\
\text { in learning course increased } \\
\text { my understanding. }\end{array}$ & $3.51(1.30)$ & & $\begin{array}{l}10.88 \\
(\mathrm{p}=.028)\end{array}$ \\
\hline $\begin{array}{l}\text { Using Facebook iframe page } \\
\text { in learning course enabled } \\
\text { me to accomplish learning } \\
\text { more quickly. }\end{array}$ & $4.11(.885)$ & & $\begin{array}{l}16.77 \\
(\mathrm{p}=.001)\end{array}$ \\
\hline $\begin{array}{l}\text { Using Facebook iframe page } \\
\text { in learning helps focus on } \\
\text { understanding the content. }\end{array}$ & $3.22(1.16)$ & & $\begin{array}{l}8.44 \\
(\mathrm{p}=.077)\end{array}$ \\
\hline $\begin{array}{l}\text { Using Facebook iframe page } \\
\text { improved my learning } \\
\text { performance. }\end{array}$ & $3.76(.857)$ & & $\begin{array}{l}15.88 \\
(\mathrm{p}=.001)\end{array}$ \\
\hline $\begin{array}{l}\text { I would find using Facebook } \\
\text { iframe useful for learning the } \\
\text { course and presenting the } \\
\text { content. }\end{array}$ & $2.89(1.22)$ & & $\begin{array}{l}9.55 \\
(\mathrm{p}=.049)\end{array}$ \\
\hline Average & $3.56(1.12)$ & & \\
\hline \multicolumn{4}{|l|}{ Ease of Use: } \\
\hline $\begin{array}{l}\text { I find learning the course } \\
\text { through Facebook iframe } \\
\text { easy to use. }\end{array}$ & $3.78(1.085)$ & \multirow[t]{2}{*}{0.691} & $\begin{array}{l}18.22 \\
(\mathrm{p}=.001)\end{array}$ \\
\hline $\begin{array}{l}\text { I find it is easy to navigate } \\
\text { between the parts of the } \\
\text { application and understand } \\
\text { its content. }\end{array}$ & $3.71(1.014)$ & & $\begin{array}{l}20.22 \\
(p=.000)\end{array}$ \\
\hline Average & $3.745(1.04)$ & & \\
\hline Overall average & $3.673(1.08)$ & & \\
\hline
\end{tabular}

\section{A. Facebook self-efficacy}

Most of the students have the ability to deal with Facebook; the results ensure that they have the basic skills for using Facebook iframe page (mean score $=3.51, x^{2}=14.88, p$ $=0.005)$. In addition, they reported that Facebook as a learning tool is attractive and motivating, and they have a desire for further learning through Facebook and learn by different ways (mean score $=3.69, \mathrm{x}^{2}=16.76, \mathrm{p}=0.003$ ).

\section{B. Attitude Toward Facebook Iframe}

The majority of students' have positive opinions that Facebook can be a hosting learning environment to improve their learning performance, and this result agrees with the findings of various other studies [14], [4], [3]. The results in (Table 3) show the mean score of all 19 items ranged from 3.39 to 3.74. The students reported that using the Facebook iframe page makes the learning stay in long-term memory (mean score $=3.76, \mathrm{x}^{2}=17.11, \mathrm{p}=0.002$ ), is attractive and amusing (mean score $=3.81, \mathrm{x}^{2}=20.42, \mathrm{p}=0.000$ ), and is helpful and more attractive than traditional learning (mean score $\left.=2.82, x^{2}=3.55, p=0.469\right)$. The students also stated that Facebook has to include all subjects and not just the current course (mean score $=3.20, \mathrm{x}^{2}=15.33, \mathrm{p}=0.004$ ).

\section{Behavioral Intention}

The students reported that they intend to use the Facebook iframe to study other courses (mean score $=3.80, x^{2}=17.77$, $\mathrm{p}=.001$ ), and they have positive views toward using the Facebook iframe as a learning tool (mean score $=3.80$, $\mathrm{x}^{2}=20.44, \mathrm{p}=.000$ ). Additionally, the students expressed that the Facebook iframe page is a good environment in which to exchange ideas and share resources (mean score $=3.87$, $\left.\mathrm{x}^{2}=18.11, \mathrm{p}=0.001\right)$. As for using Facebook as a hosting environment [28], [9], [6] they said that Facebook may be effective for this purpose because it helps them to study and view content without the need for other sites or additional software. During this study, they found they were able to learn the material easily.

\section{Outcomes and Usefulness}

In terms of enhancing outcomes, the students reported that Facebook enhanced and increased their understanding of course content (mean score $=3.51, \mathrm{x}^{2}=10.88, \mathrm{p}=.028$ ). This result is similar to other studies conducted elsewhere [11]. The respondents believe that using Facebook iframe page in learning course enabled them to accomplish learning more quickly (mean score $=4.11, \mathrm{x}^{2}=16.77, \mathrm{p}=.001$ ), and their confidence in using Facebook as a hosting environment improved. As for using the Facebook iframe page in learning to help focus on understanding the content, the students surveyed admitted their learning rate level increased (mean score $=3.22, x^{2}=8.44, p=.077$ ). The students explained that this increase occurred because they were able to create a podcast episode, online presentation, animation, and interact with the Google education app. Almost all of the students agreed that the Facebook iframe page could provide an environment for enhancing and improving their learning performance (mean score $=3.76, \mathrm{x}^{2}=15.88, \mathrm{p}=.001$ ). Indeed, students' responses indicate that they found the Facebook iframe useful for learning course material and presenting the content (mean score $=2.89, \mathrm{x}^{2}=9.55, \mathrm{p}=.049$ ).

\section{E. Ease of Use}

Students concurred that they found learning a course through the Facebook iframe easy in terms of using the application (mean score $=3.78, \mathrm{x} 2=18.22, \mathrm{p}=.001$ ). They reported that it was easy to navigate between the parts of the application and understand its content (mean score $=3.71$, $\left.\mathrm{x}^{2}=20.22, \mathrm{p}=.000\right)$.

\section{CONCLUSION}

In this paper is presented the small body of knowledge about using the Facebook iframe for learning purposes and the results of a study that suggest Facebook may be used as a hosting environment and for supporting students' learning. The majority of students surveyed reported that using the Facebook iframe page for studying a course was a positive experience. They perceived that the use of the Facebook iframe with preset content was an innovative method to support their learning outcomes and high stakes examination. 
Using Facebook iframe allows students to explore different opinions, control their own learning, and view content presented in a more effective way. Additionally, presenting content as an educational program can help students understand that content and avoid indoctrination in learning. This may support students' learning by enhancing their selfefficacy and outcomes. Importantly, students reported that working with the Facebook iframe and Facebook group was useful in helping them to learn by engaging in peer learning and exchange of experiences. A further result was that students decided that the use of the Facebook iframe as a hosting environment made them feel better prepared and that they had a deeper understanding of the content of the course. Furthermore, in our study, the Facebook iframe page provided students with a safe environment in which to focus on understanding the content of the course and engage in a deeper level of learning prior to assessment. As such, this enhanced a feeling of self-efficacy around their ability to be successful in the examination. Based on the findings of our research, we recommend integration of the Facebook iframe page as a learning tool into the resources of more university courses.

\section{REFERENCES}

[1] Baran, "Facebook as a formal instructional environment," British Journal of Educational Technology, vol.41, no. 6 (2010).pp. 146-149.

[2] B.W.O'Bannon, J. L.Beard and V. G. Britt, "Using a Facebook group as an educational tool: Effects on student achievement," Computers in the Schools, vol.30, no. 3, (2013), pp. 229-247.

[3] C.Pimmer, J.Chipps, P.Brysiewicz, F.Walters, S.Linxen and U.Gröhbiel, "Supervision on social media: Use and perception of facebook as a research education tool in disadvantaged areas," The International Review of Research in Open and Distributed Learning, vol.17, no. 5, (2016), pp. 201-214.

[4] C.Pimmer, S.Linxen, and U.Gröhbiel, "Facebook as a learning tool? A case study on the appropriation of social network sites from mobile phones in developing countries," British Journal of Educational Technology, vol.43, no. 5 ,(2012), pp. 726-738.

[5] E.Miron and G.Ravid, "Facebook Groups as an Academic Teaching Aid: Case Study and Recommendations for Educators," Journal of Educational Technology \& Society, vol.18, no. 4, (2015), pp. 371-384.

[6] G. Y. Lin, Effects that Facebook-based Online Peer Assessment with Micro-teaching Videos Can Have on Attitudes toward Peer Assessment and Perceived Learning from Peer Assessment," Eurasia Journal of Mathematics, Science \& Technology Education, vol.12, no.9, (2016).

[7] G.Grossecka, R.Branb, and L.Tiruc, "Dear teacher, what should I write on my wall? A case study on academic uses of Facebook," ProcediaSocial and Behavioral Sciences, vol.15, (2011), pp. 1425-1430.

[8] H. M.Tal1, G.Kurtz and E.Pieterse, Facebook Groups as LMS: A Case Study. International Review of Research in Open \& Distance Learning., 13(4), (2012), pp. 33-48.

[9] J. C. Clements1, "Using Facebook to enhance independent student engagement: a case study of first-year undergraduates," Higher Education Studies, vol.5, no. 4 (2015), pp.131-146.

[10] J. P.Mazer, R. E.Murphy and C. J. Simonds, "I'll see you on "Facebook": The effects of computer-mediated teacher self-disclosure on student motivation, affective learning, and classroom climate." Communication Education, vol.56, no. 1 (2007), pp. 1-17.

[11] K. F.Hew and W. S. Cheung, "Use of Facebook: a case study of Singapore students' experience," Asia Pacific Journal of Education, vol.32, no. 2 (2012), pp.181-196.

[12] K. M.Titi, and A. Muhammad, Improvement Quality of LMS Through Application of Social Networking Sites. International Journal of Emerging Technologies in Learning., 8(3), (2013). Pp.48-51.
[13] K.huwe, "Twitter and Facebook Open the Door to Collaboration," Computers in Libraries, vol.32, no. 8 (2012), pp. 27-29.

[14] M. K. Kabilan, N.Ahmad, and M. a. Abidin, "Facebook: An online environment for learning of English in institutions of higher education? " The Internet and higher education, vol.13, no. 4, (2010), pp. 179-187.

[15] M. C.Pretorius and D.Villiers, "Evaluation of a Collaborative Learning Environment on a Facebook". Electronic Journal of Information Systems Evaluation, 16(1), (2013). Pp.58-72.

[16] M.Amasha and S.Alkhalaf, "The effect of using facebook markup language (fbml) for designing an e-learning model in higher education," international journal of research in computer science, vol.5 (2015), pp. $1-9$.

[17] M.Amasha and S.Alkhalaf, "Using RSS 2.00 as a Model for u-Learning to Develop e-Training in Saudi Arabia". International Journal of Information and Education Technology, 6(7),(2016),p.516.

[18] M.Tower, S.Latimer and J.Hewitt, "Social networking as a learning tool: Nursing students' perception". Nurse Education Today, vol.34, no. 6 (2014), pp. 1012-1017.

[19] O.Sanghee and S. S.Yeon, "Motivations for sharing information and social support in social media: A comparative analysis of Facebook, Twitter, Delicious, You Tube, and Flickr", Journal of the Association for Information Science \& Technology, 66(10), (Oct2015). Pp.2045-2060.

[20] P.Ractham and L.Kaewkitipong, "The use of Facebook in an introductory MIS course: Social constructivist learning environment," Decision Sciences Journal of Innovative Education, vol.10, no. 2 (2012), pp. 165-188.

[21] Q.wang, H. 1.woo, C. l.quek, Y.yang, , and M.liu, "using the facebook group as a learning management system: an exploratory study . brith journal of education technology , 43(3), (2012), Pp. 428-438.

[22] R. A. Sánchez, V.Cortijio and U. Javed, "Students' perceptions of Facebook for academic purposes," Computers \& Education, vol.70 (2014), pp. 138-149.

[23] R.Junco, The relationship between frequency of Facebook use, participation in Facebook activities, and student engagement." Computers \& Education, vol.58, no. 1 (2012), pp. 162-171.

[24] S. Aydin. "A review of research on Facebook as an educational environment". Educational Technology Research \& Development. , 60(6), (2012),PP. 1093-1106.

[25] S. G.Mazman and Y. K. Usluel, "Modeling educational usage of Facebook." Computers \& Education, vol.55, no. 2 ,(2010), pp.444-453.

[26] S. H.Sarapin and P. L. Morris,"Faculty and Facebook friending: instructor-student online social communication from the professor's perspective," The Internet and Higher Education, vol.27 (2015), pp. 1423.

[27] S.Hamid, J.Waycott, S.Kurnia, and S.Chang, "Understanding students' perceptions of the benefits of online social networking use for teaching and learning," The Internet and Higher Education, vol.26, (2015), pp. 19.

[28] S.Khana and , S. B. Tahir, "A Study on the Role of Facebook in ELearning”. I.J. Education and Management Engineering, 5, (2015),pp.111. doi:0.5815/ijeme.2015.05.01

[29] S.Manca and M.Ranieri, "Facebook and the others. Potentials and obstacles of social media for teaching in higher education," Computers \& Education, vol.95, (2016), pp. 216-230.

[30] T. Arabacioglu and R. A.Vural, "Using Facebook AS A Lms?" Turkish Online Journal of Educational Technology., 13(2), (2014). PP. 202-215.

[31] T. J.Sinclair and R.Grieve, "Facebook as a source of social connectedness in older adults." Computers in Human Behavior, vol. 66 (2017), pp. 363-369.

[32] V.Kharitonov and V. T . Sergei, "Dynamics and Structure of Dispute in Open Group of Facebook Social Networking Service in Terms of Teenagers' Homosexual Relations Education," European researcher, Series A 5-1, (2014), pp. 882-910.

[33] Y. J. Joo, K. Y.Lim and N. H. Kim, "The effects of secondary teachers' technostress on the intention to use technology in South Korea," Computers \& Education, vol.95, (2016), pp. 114-122. 